\title{
Oxidation of DL - Methionine by Imidazolium Chlorochromate and Benzimidazolium Chlorochromate in Aqueous Perchlorate Medium
}

\author{
ALAKA DAS and P. MOHANTY \\ Department of Chemistry, Utkal University, Vanivihar, Bhubaneswar, Odisha-751004, India \\ alaka_das11@yahoo.in
}

Received 29 June 2012 / Accepted 22 July 2012

\begin{abstract}
The oxidation of methionine by oxidants such as imidazolium chlorochromate (ICC) and benzimidazolium chlorochromate $(\mathrm{BCC})$ in aqueous perchlorate medium has been studied spectrophotometrically over the range $3.00 \leq 10^{3}$ [methionine] $\leq 6.00,0.01 \leq\left[\mathrm{H}^{+}\right] \leq 0.03 \mathrm{~mol} \mathrm{dm}^{-3}$ and $20{ }^{\circ} \mathrm{C} \leq \mathrm{T} \leq 40{ }^{\circ} \mathrm{C}$. The rate of reaction was found to increase with the increase of total concentration of methionine and total concentration of $\mathrm{H}^{+}$. The reaction was found to exhibit first order dependence in [methionine], $\left[\mathrm{H}^{+}\right]$and the oxidants [ICC] and [BCC]. The $\Delta \mathrm{H}^{\neq}(\mathrm{kJ} / \mathrm{mol})$ and $\Delta \mathrm{S}^{\ddagger}\left(\mathrm{JK}^{-1} \mathrm{~mol}^{-1}\right)$ for the electron transfer reaction were found to be 12.5 and -154.1 in case of ICC and 17.53 and -136.9 in case of $\mathrm{BCC}$ respectively. The product of the reaction was found to be methionine sulphoxide. The negative values of $\Delta \mathrm{S}^{\neq}$support ordered transition state for both the electron transfer reactions due to ICC and BCC.
\end{abstract}

Keywords: Imidazolium chlorochromate, Benzimidazolium chlorochromate, Methionine, Electron transfer

\section{Introduction}

A survey of literature shows that kinetics and mechanism of oxidation of methionine (Figure 1) by various oxidants are well understood ${ }^{1-5}$. ICC (Figure 2) and BCC (Figure 3) are mild oxidizing agents. The redox reactions of methionine with other oxidant like pyridinium ${ }^{6}$, substituted pyridinium ${ }^{7}$, nicotinium ${ }^{8}$, prolinium $^{9}$ chlorochromate have been studied. However methionine is reported to behave differently in comparison to other amino acids towards many oxidants ${ }^{10-12}$. Due to presence of electron rich sulphur centre which is easily oxidisable, strong oxidant such as $\mathrm{Cr}(\mathrm{VI})^{13,14}$ oxidises methionine to methioninesulphoxide and subsequently to sulfone. The sulphur containing amino acid and peptide oxidation reactions are studied mostly for their biological importance ${ }^{15,16}$. DL - methionine has $\mathrm{O}, \mathrm{N} \& \mathrm{~S}$ as three coordinating centers. Of these sulphur has been established as the most susceptible to attack by the oxidants. The compound has been used extensively for the study of redox reactions of many biomolecules, but the electron transfer reaction of oxidant such as ICC and $\mathrm{BCC}$ with methionine has not been studied. In order to understand the electron transfer reaction, the work has been undertaken. 
<smiles>CSCC[C@H](N)C(=O)O</smiles>

methionine<smiles></smiles>

imidazolium chlorochromate

Figure 2<smiles>O=S(=O)(Cl)Cl</smiles>

benzimidazolium chlorochromate

Figure 3

\section{Experimental}

The oxidants ICC and BCC were prepared and characterized according to reported method ${ }^{17,18}$. All other chemicals used were of AnalaR grade. Doubly distilled water was used to prepare all the solutions. The acid strength of the medium was maintained by addition of $\mathrm{HClO}_{4}$. Kinetic measurements were recorded on a SYTRONIC 119 PC scanning UV-Vis spectrophotometer. Reaction progress was monitored at $350 \mathrm{~nm}$. (Figure 4(A) for ICC and 4(B) for BCC) Pseudo first order condition were maintained throughout the runs by using a large excess ( $>5$ fold) of methionine. The constant $\left(k_{o b s}\right)$ were obtained from the slope of $-\ln \left(A_{t}-A_{\infty}\right)$ versus 't' plots. $-\ln \left(A_{t}-A_{\infty}\right)=k_{\text {obs }} \mathrm{t}-\mathrm{C}$.

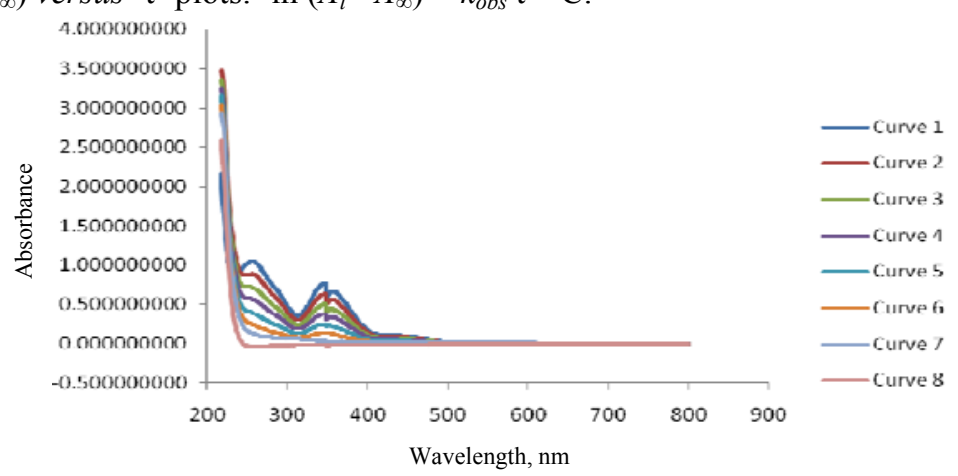

Figure 4(A). Repetitive spectral scan of $[\mathrm{ICC}]_{\mathrm{T}}=4 \times 10^{-4} \mathrm{~mol} \mathrm{dm}{ }^{-3}$ Curve 1, with Methionine $=2 \times 10^{-3} \mathrm{~mol} \mathrm{dm}^{-3}$ Curve $8,\left[\mathrm{H}^{+}\right]=1.0 \times 10^{-2} \mathrm{~mol} \mathrm{dm}^{-3}$, Tempreture $=30{ }^{\circ} \mathrm{C}$, At different time intervals $\Delta \mathrm{t}=5$ minutes (Curve 2-6), Curve 7 is after $24 \mathrm{~h}$

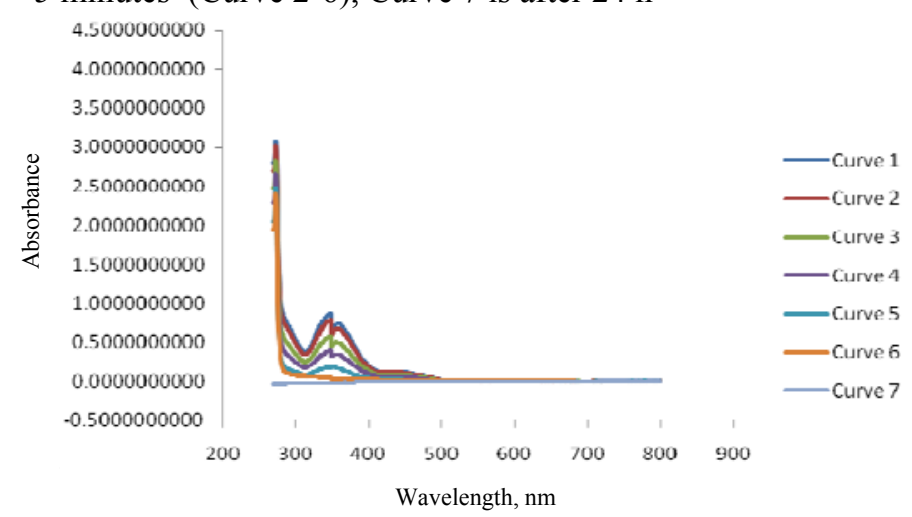

Figure 4(B). Repetitive spectral scan of $[\mathrm{BCC}]_{\mathrm{T}}=4 \times 10^{-4} \mathrm{~mol} \mathrm{dm}^{-3}$, Curve 1, with $[\text { Methionine }]_{\mathrm{T}}=2 \times 10^{-3} \mathrm{~mol} \mathrm{dm}^{-3}$, Curve $7,\left[\mathrm{H}^{+}\right]=1.0 \times 10^{-2} \mathrm{~mol} \mathrm{dm}{ }^{-3}$, Tempreture $=30^{\circ} \mathrm{C}$, At different time intervals $\Delta t=5$ minutes (Curve 2-5), Curve 6 is after $24 \mathrm{~h}$ 
Where $A_{t}$ and $A_{\infty}$ are the absorbances of the reaction mixture at time ' $\mathrm{t}$ ' and at the completion of the reaction. The reported rate data represented as an average of duplicate runs were reproducible within $\pm 3 \%$. The correlation coefficients of the plots used to determine $k_{o b s}$ were found to be 0.99 in most of the cases.

\section{Results and Discussion}

The kinetic results obtained for the above reaction may be summarized as follows. With varying concentration of $10^{3}$ [methionine $]_{\mathrm{T}}$ in the range 3.00 to $6.00 \mathrm{~mol} \mathrm{dm}{ }^{-3}$, the $10^{4} k_{\text {obs }} / \mathrm{s}^{-1}$ at $\left(25^{0} \mathrm{C}\right)$ increased from 5.60 to 8.96 in case of ICC and 6.95 to 11.52 in case of BCC when $\left[\mathrm{H}^{+}\right]=0.01 \mathrm{~mol} \mathrm{dm}^{-3},[\mathrm{ICC}]=4 \times 10^{-4} \mathrm{~mol} \mathrm{dm}^{-3}$ (Table $1(\mathrm{~A})$ for ICC and $1(\mathrm{~B})$ for BCC). The [methionine]/ [ICC] or [BCC] was varied from 5.00 to 15.00 . The $k_{o b s}$ versus [methionine] plot (Figure 5(A) in case of ICC and 5(B) for BCC) were linear at all reported $\left[\mathrm{H}^{+}\right]$indicating $1^{\text {st }}$ order dependence of the reaction on [methionine]. As the order of the reaction is one with respect to [methionine] and over all order of the reaction is two and the order with respect to $[\mathrm{ICC}]$ or $[\mathrm{BCC}]$ is one. The rate law is therefore given by equation (1).

$$
\text { Rate }=k_{\text {obs }}\left\{[\mathrm{ICC}]_{\mathrm{T}} \text { or }[\mathrm{BCC}]_{\mathrm{T}}\right\}
$$

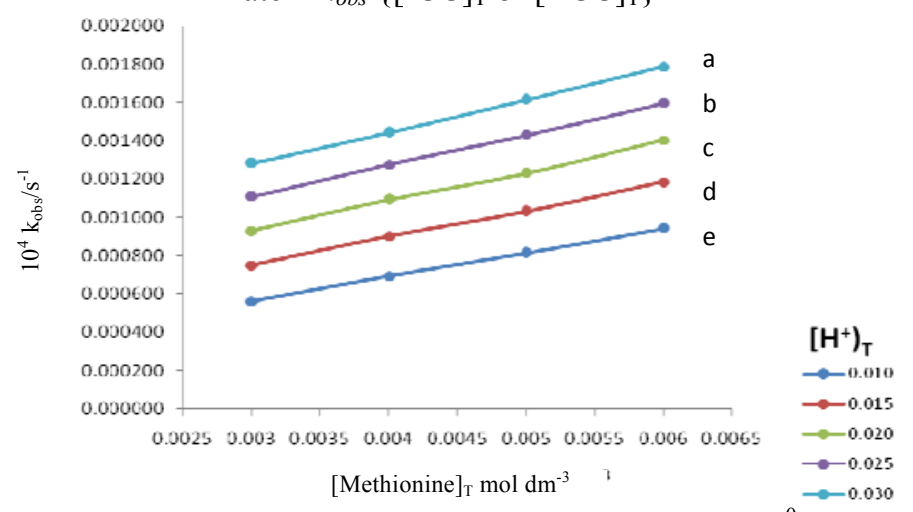

Figure 5(A). Plot of $k_{\text {obs }}$ versus [methionine]; (Oxidant $=\mathrm{ICC}, \mathrm{T}=25{ }^{0} \mathrm{C}$ where $\mathrm{a}:\left[\mathrm{H}^{+}\right]_{\mathrm{T}}=0.010$ $\mathrm{mol} \mathrm{dm}{ }^{-3}, \mathrm{~b}:\left[\mathrm{H}^{+}\right]_{\mathrm{T}}=0.015 \mathrm{~mol} \mathrm{dm}{ }^{-3}, \mathrm{c}:\left[\mathrm{H}^{+}\right]_{\mathrm{T}}=0.020 \mathrm{~mol} \mathrm{dm}^{-3}, \mathrm{~d}:\left[\mathrm{H}^{+}\right]_{\mathrm{T}}=0.025 \mathrm{~mol} \mathrm{dm}^{-3}, \mathrm{e}:$ $\left[\mathrm{H}^{+}\right]_{\mathrm{T}}=0.030 \mathrm{~mol} \mathrm{dm}^{-3}$ )

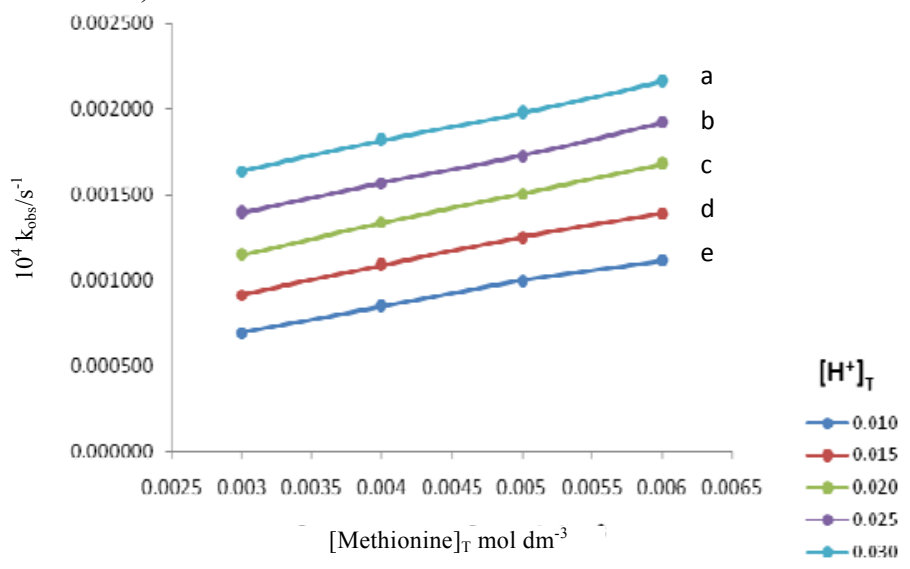

Figure 5(B). Plot of $k_{\text {obs }}$ versus [methionine]; (Oxidant $=\mathrm{BCC}, \mathrm{T}=25{ }^{0} \mathrm{C}$ where $\mathrm{a}:\left[\mathrm{H}^{+}\right]_{\mathrm{T}}=0.010$ $\mathrm{mol} \mathrm{dm}, \mathrm{b}:\left[\mathrm{H}^{+}\right]_{\mathrm{T}}=0.015 \mathrm{~mol} \mathrm{dm}{ }^{-3}, \mathrm{c}:\left[\mathrm{H}^{+}\right]_{\mathrm{T}}=0.020 \mathrm{~mol} \mathrm{dm}{ }^{-3}, \mathrm{~d}:\left[\mathrm{H}^{+}\right]_{\mathrm{T}}=0.025 \mathrm{~mol} \mathrm{dm}^{-3}, \mathrm{e}$ : $\left[\mathrm{H}^{+}\right]_{\mathrm{T}}=0.030 \mathrm{~mol} \mathrm{dm}^{-3}$ ) 
With [ICC] or $[\mathrm{BCC}]=4 \times 10^{-4} \mathrm{~mol} \mathrm{dm}^{-3}$ and [methionine $]=3 \times 10^{-3} \mathrm{~mol} \mathrm{dm}^{-3}, 10^{4} k_{\text {obs }}$ at $\left(25{ }^{0} \mathrm{C}\right)$ changed from 5.60 to 12.83 in case of ICC and 6.95 to 16.38 in case of BCC respectively as $\left[\mathrm{H}^{+}\right]$was changed from 0.01 to $0.03 \mathrm{~mol} \mathrm{dm}^{-3}$. This behavior was repeated for the entire [methionine] range 0.003 to $0.006 \mathrm{~mol} \mathrm{dm}^{-3}$ (Figure 6(A) for ICC and 6(B) for BCC).

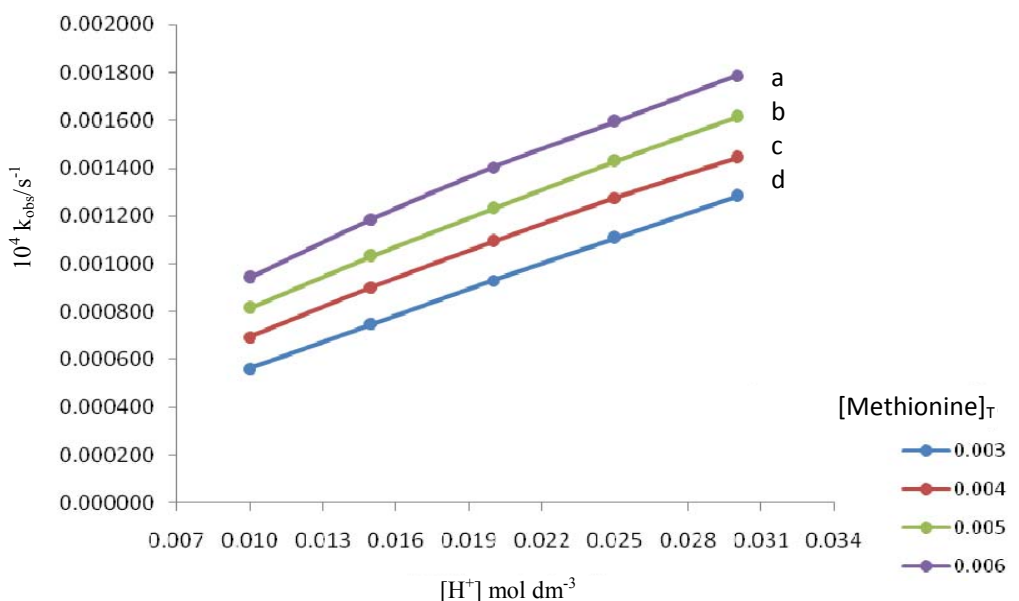

Figure 6(A). Plot of $k_{\text {obs }}$ versus $\left[\mathrm{H}^{+}\right]$; (Oxidant $=\mathrm{ICC}, \mathrm{T}=25{ }^{0} \mathrm{C}$ where a: $[\mathrm{Met}]_{\mathrm{T}}=0.003 \mathrm{~mol}^{-1}$ $\mathrm{dm}^{3}, \mathrm{~b}:[\mathrm{Met}]_{\mathrm{T}}=0.004 \mathrm{~mol}^{-1} \mathrm{dm}^{3}, \mathrm{c}:[\mathrm{Met}]_{\mathrm{T}}=0.005 \mathrm{~mol}^{-1} \mathrm{dm}^{3}, \mathrm{~d}:[\mathrm{Met}]_{\mathrm{T}}=0.006 \mathrm{~mol}^{-1} \mathrm{dm}^{3}$

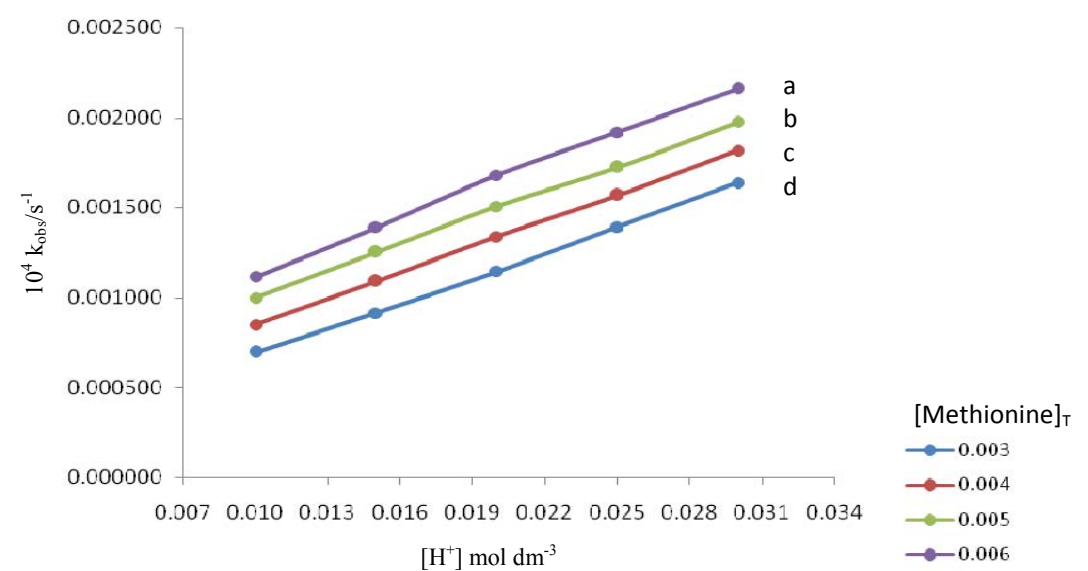

Figure 6(B). Plot of $k_{\text {obs }}$ versus $\left[\mathrm{H}^{+}\right]$; (Oxidant $=\mathrm{BCC}, \mathrm{T}=25{ }^{0} \mathrm{C}$ where a:[Met $]_{\mathrm{T}}=0.003 \mathrm{~mol}^{-1}$ $\mathrm{dm}^{3}, \mathrm{~b}:[\mathrm{Met}]_{\mathrm{T}}=0.004 \mathrm{~mol}^{-1} \mathrm{dm}^{3}, \mathrm{c}:[\mathrm{Met}]_{\mathrm{T}}=0.005 \mathrm{~mol}^{-1} \mathrm{dm}^{3}, \mathrm{~d}:[\mathrm{Met}]_{\mathrm{T}}=0.006 \mathrm{~mol}^{-1} \mathrm{dm}^{3}$

The effect of temperature was studied in the range 20 to $40{ }^{\circ} \mathrm{C}$. With the increase in temperature, $k_{o b s}$ was found to increase. With [methionine] $=3 \times 10^{-3} \mathrm{~mol} \mathrm{dm}^{-3}$ [ICC] or $[\mathrm{BCC}]=4 \times 10^{-4} \mathrm{~mol} \mathrm{dm}{ }^{-3},\left[\mathrm{H}^{+}\right]=0.01 \mathrm{~mol} \mathrm{dm}^{-3}, 10^{4} k_{\text {obs }} / \mathrm{s}^{-1}$ changed from 3.09 to 7.59 in case of ICC and 4.24 to 10.35 in case of BCC (Table 1(A) for ICC and 1(B) for BCC).

\section{Stoichiometry and mechanism}

The stoichiometry of the reaction was studied at $30{ }^{\circ} \mathrm{C}$ where [ICC] or [BCC] was kept constant at $4.00 \times 10^{-4} \mathrm{~mol} \mathrm{dm}^{-3}$ and $[$ methionine $]=6.00 \times 10^{-3} \mathrm{~mol} \mathrm{dm}^{-3}$, the $\left[\mathrm{H}^{+}\right]=0.01 \mathrm{~mol} \mathrm{dm}^{-3}$. From the decrease in $[\mathrm{ICC}]$ or $[\mathrm{BCC}]$ and [methionine] the stoichiometry of the reaction can be written as; 


$$
3 \mathrm{Me}-\mathrm{S}-\mathrm{R}+2[\mathrm{Ox}] \longrightarrow 3 \mathrm{Me}-\underset{\mathrm{O}}{\mathrm{S}}-\mathrm{R}+2 \mathrm{Cr}(\mathrm{III})
$$

Where $\mathrm{R}=-\mathrm{CH}_{2}-\mathrm{CH}_{2}-\mathrm{CH}-\mathrm{COOH}$<smiles>N</smiles>

and $[\mathrm{Ox}]$ means oxidants i.e. ICC or BCC.

Table 1(A). Effect of temperature (ICC)

\begin{tabular}{ccccccc}
\hline & \multirow{2}{*}{ Temp, ${ }^{\circ} \mathrm{C}$} & $10^{3}\left[\mathrm{Meth}_{\mathrm{T}}\right.$ \\
\cline { 3 - 6 } & & \multicolumn{5}{c}{$10^{4} k_{\text {obs }}, \mathrm{s}^{-1}$} \\
\cline { 3 - 6 }$\left[\mathrm{H}^{+}\right], \mathrm{mol} \mathrm{dm}^{-3}$ \\
\cline { 3 - 6 } & & 0.010 & 0.015 & 0.020 & 0.025 & 0.030 \\
\hline 20 & 3.0 & 4.46 & 6.35 & 8.17 & 9.94 & 11.69 \\
30 & 3.0 & 5.60 & 7.49 & 9.31 & 11.08 & 12.83 \\
35 & 3.0 & 6.49 & 8.38 & 10.20 & 11.97 & 13.72 \\
40 & 3.0 & 7.64 & 9.53 & 11.35 & 13.12 & 14.87 \\
20 & 3.0 & 8.96 & 10.85 & 12.67 & 14.44 & 16.19 \\
25 & 4.0 & 5.79 & 7.88 & 9.80 & 11.61 & 13.30 \\
30 & 4.0 & 6.93 & 9.02 & 10.94 & 12.75 & 14.44 \\
35 & 4.0 & 7.82 & 9.91 & 11.83 & 13.64 & 15.33 \\
40 & 4.0 & 8.97 & 11.06 & 12.98 & 14.79 & 16.48 \\
20 & 4.0 & 10.29 & 12.38 & 14.30 & 16.11 & 17.80 \\
25 & 5.0 & 6.99 & 9.18 & 11.16 & 13.16 & 15.00 \\
30 & 5.0 & 8.13 & 10.32 & 12.30 & 14.30 & 16.14 \\
35 & 5.0 & 9.02 & 11.21 & 13.19 & 15.19 & 17.03 \\
40 & 5.0 & 10.17 & 12.36 & 14.34 & 16.34 & 18.18 \\
20 & 5.0 & 11.49 & 13.68 & 15.66 & 17.66 & 19.50 \\
25 & 6.0 & 8.27 & 10.72 & 12.90 & 14.80 & 16.72 \\
30 & 6.0 & 9.41 & 11.86 & 14.04 & 15.94 & 17.86 \\
35 & 6.0 & 10.30 & 12.75 & 14.93 & 16.83 & 18.75 \\
40 & 6.0 & 11.45 & 13.90 & 16.08 & 17.98 & 19.90 \\
& 6.0 & 12.77 & 15.22 & 17.40 & 19.30 & 21.22 \\
\hline
\end{tabular}

\begin{tabular}{|c|c|c|c|c|c|c|}
\hline \multirow{3}{*}{ Temp / ${ }^{\circ} \mathrm{C}$} & \multirow{3}{*}{$\begin{array}{l}10^{3}[\text { Meth }]_{\mathrm{T}} \\
/ \mathrm{mol} \mathrm{dm}^{-3}\end{array}$} & \multicolumn{5}{|c|}{$10^{4} k_{\text {obs }} / \mathrm{s}^{-1}$} \\
\hline & & \multicolumn{5}{|c|}{$\left[\mathrm{H}^{+}\right] / \mathrm{mol} \mathrm{dm}^{-3}$} \\
\hline & & 0.010 & 0.015 & 0.020 & 0.025 & 0.030 \\
\hline 20 & 3.0 & 5.41 & 7.60 & 9.92 & 12.39 & 14.84 \\
\hline 25 & 3.0 & 6.95 & 9.14 & 11.46 & 13.93 & 16.38 \\
\hline 30 & 3.0 & 8.08 & 10.27 & 12.59 & 15.06 & 17.51 \\
\hline 35 & 3.0 & 9.90 & 12.09 & 14.41 & 16.88 & 19.33 \\
\hline 40 & 3.0 & 11.52 & 13.71 & 16.03 & 18.50 & 20.95 \\
\hline 20 & 4.0 & 6.94 & 9.36 & 11.84 & 14.15 & 16.64 \\
\hline 25 & 4.0 & 8.48 & 10.90 & 13.38 & 15.69 & 18.18 \\
\hline 30 & 4.0 & 9.61 & 12.03 & 14.51 & 16.82 & 19.31 \\
\hline 35 & 4.0 & 11.43 & 13.85 & 16.33 & 18.64 & 21.13 \\
\hline 40 & 4.0 & 13.05 & 15.47 & 17.95 & 20.26 & 22.75 \\
\hline
\end{tabular}

Table 1(B). Effect of temperature (BCC) 


\begin{tabular}{lcccccc}
\hline 20 & 5.0 & 8.44 & 10.98 & 13.51 & 15.71 & 18.23 \\
25 & 5.0 & 9.98 & 12.52 & 15.05 & 17.25 & 19.77 \\
30 & 5.0 & 11.11 & 13.65 & 16.18 & 18.38 & 20.90 \\
35 & 5.0 & 12.93 & 15.47 & 18.00 & 20.20 & 22.72 \\
40 & 5.0 & 14.55 & 17.09 & 19.62 & 21.82 & 24.34 \\
20 & 6.0 & 9.62 & 12.37 & 15.25 & 17.65 & 20.07 \\
25 & 6.0 & 11.16 & 13.91 & 16.79 & 19.19 & 21.61 \\
30 & 6.0 & 12.29 & 15.04 & 17.92 & 20.32 & 22.74 \\
35 & 6.0 & 14.11 & 16.86 & 19.74 & 22.14 & 24.56 \\
40 & 6.0 & 15.73 & 18.48 & 21.36 & 23.76 & 26.18 \\
\hline
\end{tabular}

At higher concentration of the acid $0.03 \mathrm{~mol} \mathrm{dm}^{-3}$, the undissociated form of methionine will participate in the electron transfer reaction. The reaction sequence presented below (Scheme 1) is consistent with the experimental data.

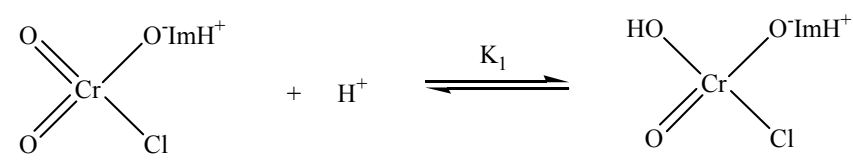

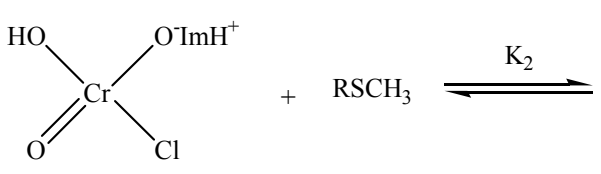

$\mathrm{C}_{1}$<smiles>[R][Si](C)(C)C(=O)O</smiles>

Scheme 1. The above scheme for ICC (same in case of BCC)

$$
\begin{gathered}
\mathrm{C}_{2} \stackrel{\mathrm{k}_{1}}{\longrightarrow} \mathrm{Cr}(\mathrm{IV})+\mathrm{R}\left(\mathrm{CH}_{3}\right) \mathrm{SO} \\
2 \mathrm{Cr}(\mathrm{IV}) \stackrel{\text { Fast }}{\longrightarrow} 2 \mathrm{Cr}(\mathrm{III})+\mathrm{Cr}(\mathrm{V}) \\
\mathrm{Cr}(\mathrm{V})+\mathrm{RSCH}_{3} \stackrel{\text { Fast }}{\longrightarrow} \mathrm{Cr}(\mathrm{III})+\mathrm{R}\left(\mathrm{CH}_{3}\right) \mathrm{SO}
\end{gathered}
$$

The rate of law for the electron transfer reaction can be derived in the following manner $K_{2}=\left[\mathrm{C}_{2}\right]_{\mathrm{e}} /\left[\mathrm{C}_{1}\right]_{\mathrm{e}}[$ methionine $]$

$$
\text { Rate }=k_{I}\left[\mathrm{C}_{2}\right]_{\mathrm{e}}
$$

$$
\left[\mathrm{C}_{2}\right]_{\mathrm{e}}=K_{2}\left[\mathrm{C}_{2}\right]_{\mathrm{e}} \text { [methionine] }
$$

Substituting the value of $\left[\mathrm{C}_{2}\right]_{\mathrm{e}}$ in Equation 8

$$
\begin{aligned}
\text { Rate } & =k_{l} K_{2}\left[\mathrm{C}_{1}\right]_{\mathrm{e}}[\text { methionine }]_{\mathrm{e}} \\
K_{l} & =\left[\mathrm{C}_{1}\right]_{\mathrm{e}} /[\mathrm{Ox}]_{\mathrm{e}}\left[\mathrm{H}^{+}\right]_{\mathrm{e}} \\
{\left[\mathrm{C}_{1}\right]_{\mathrm{e}} } & =K_{l}[\mathrm{Ox}]_{\mathrm{e}}\left[\mathrm{H}^{+}\right]_{\mathrm{e}}
\end{aligned}
$$

Substituting the value of $\left[\mathrm{C}_{1}\right]_{\mathrm{e}}$ in the Equation 10

$$
\begin{aligned}
\text { Rate } & =k_{l} K_{l} K_{2}\left[\mathrm{H}^{+}\right]_{\mathrm{e}}[\mathrm{Ox}]_{\mathrm{e}}[\text { methionine }]_{\mathrm{e}} \\
{[\mathrm{Ox}]_{\mathrm{T}} } & =[\mathrm{Ox}]_{\mathrm{e}}+\left[\mathrm{C}_{1}\right]_{\mathrm{e}} \\
& =[\mathrm{Ox}]_{\mathrm{e}}+K_{l}[\mathrm{Ox}]_{\mathrm{e}}\left[\mathrm{H}^{+}\right]_{\mathrm{e}} \\
& =[\mathrm{Ox}]_{\mathrm{e}}\left\{1+K_{l}\left[\mathrm{H}^{+}\right]_{\mathrm{e}}\right\}
\end{aligned}
$$




$$
\begin{aligned}
{[\mathrm{Ox}]_{\mathrm{e}} } & =\frac{[\mathrm{Ox}]_{\mathrm{T}}}{1+K_{l}\left[\mathrm{H}^{+}\right]_{\mathrm{e}}} \\
\text { Rate } & =\frac{k_{l} K_{l} K_{2}[\mathrm{Ox}]_{\mathrm{T}}\left[\mathrm{H}^{+}\right]_{\mathrm{e}}[\text { methionine }]_{\mathrm{e}}}{1+K_{l}\left[\mathrm{H}^{+}\right]_{\mathrm{e}}} \\
\text { Since rate } & =k_{o b s}[\mathrm{Ox}]_{\mathrm{T}} \\
k_{o b s} & =\frac{k_{l} K_{l} K_{2}[\text { Methionine }]_{\mathrm{e}}\left[\mathrm{H}^{+}\right]_{\mathrm{e}}}{1+K_{l}\left[\mathrm{H}^{+}\right]_{\mathrm{e}}}
\end{aligned}
$$

The plot of $k_{o b s}{ }^{-1}$ versus $\left[\mathrm{H}^{+}\right]^{-1}$ should be linear for every [methionine] changing from $3.00 \times 10^{-3}$ to $6.00 \times 10^{-3} \mathrm{~mol} \mathrm{dm}^{-3}$ (Figure 7(A) for ICC and 7(B) for BCC). The slope of this plot is $\left\{1 / k_{l} K_{l} K_{2}\right.$ [methionine] $\}$ and intercept is $\left\{1 / k_{l} K_{2}\right.$ [methionine] $\}$. Now from this value of $K_{l}$ can be calculated i.e. intercept/slope $=K_{l}$. The values of $K_{l}$ were determined for five different temperatures ranging from $20^{\circ}$ to $40{ }^{\circ} \mathrm{C}$ and found to be $22.32,33.14,41.50,52.25,64.51$ respectively in case of ICC and 20.10, 31.77, 40.26, 53.82, 65.81 respectively in case of BCC.

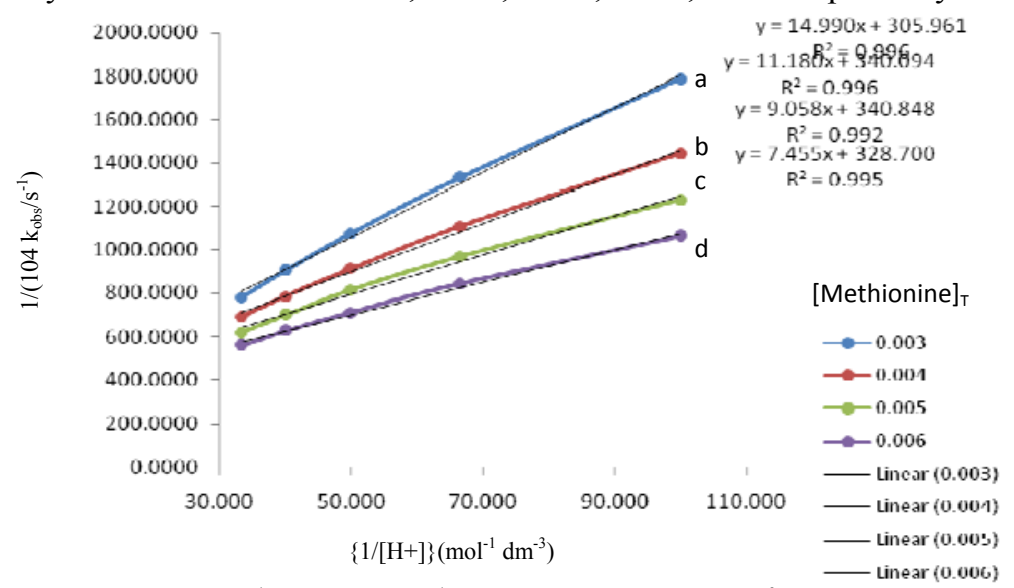

Figure 7(A). Plot of $k_{\text {obs }}{ }^{-1}$ versus $\left[\mathrm{H}^{+}\right]^{-1}$ (Oxidant : ICC, $\mathrm{T}=25{ }^{0} \mathrm{C}$ where a:[Met $]_{\mathrm{T}}=0.003 \mathrm{~mol}^{-1}$ $\mathrm{dm}^{3}, \mathrm{~b}:[\mathrm{Met}]_{\mathrm{T}}=0.004 \mathrm{~mol}^{-1} \mathrm{dm}^{3}, \mathrm{c}:[\mathrm{Met}]_{\mathrm{T}}=0.005 \mathrm{~mol}^{-1} \mathrm{dm}^{3}, \mathrm{~d}:[\mathrm{Met}]_{\mathrm{T}}=0.006 \mathrm{~mol}^{-1} \mathrm{dm}^{3}$

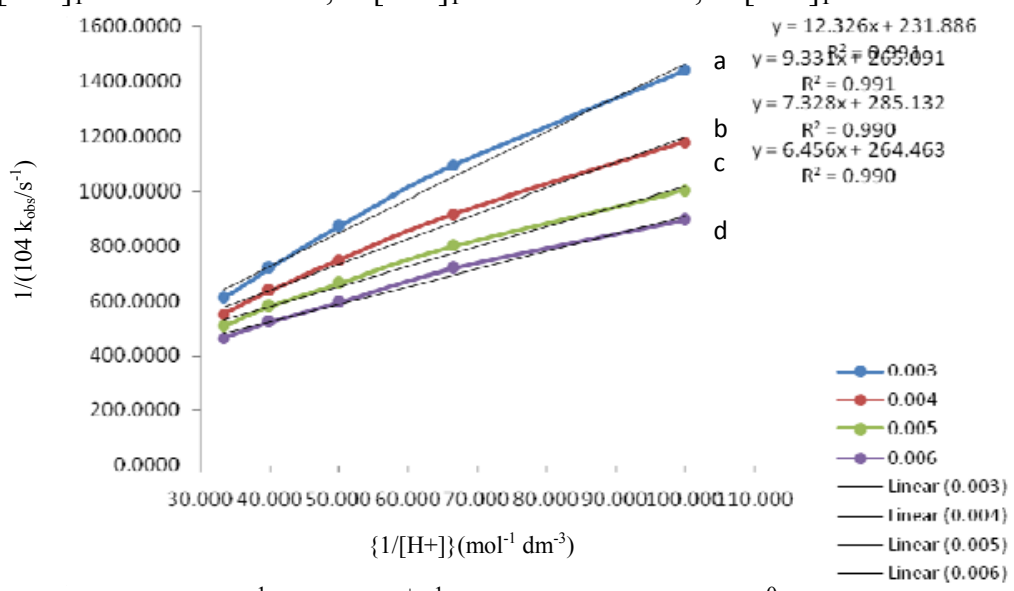

Figure 7(B). Plot of $k_{o b s}^{-1}$ versus $\left[\mathrm{H}^{+}\right]^{-1}$ (Oxidant : $\mathrm{BCC}, \mathrm{T}=25^{0} \mathrm{C}$ where $\mathrm{a}:[\mathrm{Met}]_{\mathrm{T}}=0.003 \mathrm{~mol}^{-1}$ $\mathrm{dm}^{3}, \mathrm{~b}:[\mathrm{Met}]_{\mathrm{T}}=0.004 \mathrm{~mol}^{-1} \mathrm{dm}^{3}, \mathrm{c}:[\mathrm{Met}]_{\mathrm{T}}=0.005 \mathrm{~mol}^{-1} \mathrm{dm}^{3}, \mathrm{~d}:[\mathrm{Met}]_{\mathrm{T}}=0.006 \mathrm{~mol}^{-1} \mathrm{dm}^{3}$ 
The slope of each $\left[\mathrm{H}^{+}\right]$was plotted against $[\text {methionine }]^{-1}$. The plots are found to be linear (Figure $8(\mathrm{~A})$ for ICC and $8(\mathrm{~B})$ for BCC). The slope of Figure 8 (A) and (B) will be equal to $\left\{1 / k_{1} K_{l} K_{2}\right\}$. The value of $k_{l} K_{l} K_{2}$ will be equal to reciprocal of the new slope. The values of $k_{1} K_{l} K_{2}$ were determined for four different temperatures ranging from $20{ }^{\circ} \mathrm{C}$ to $40{ }^{0} \mathrm{C}$. The activation parameters were determined from the composite rate constants by using Eyring equation. The value of the $\Delta \mathrm{H}^{\neq}$and $\Delta \mathrm{S}^{\neq}$were found to be $12.5(\mathrm{~kJ} / \mathrm{mol})$ and $154.1\left(\mathrm{JK}^{-1} \mathrm{~mol}^{-1}\right)$ in case of ICC and $17.5(\mathrm{~kJ} / \mathrm{mol})$ and $-136.9\left(\mathrm{JK}^{-1} \mathrm{~mol}^{-1}\right)$ in case of BCC respectively. The negative value of activation parameters favors the formation order transition states.
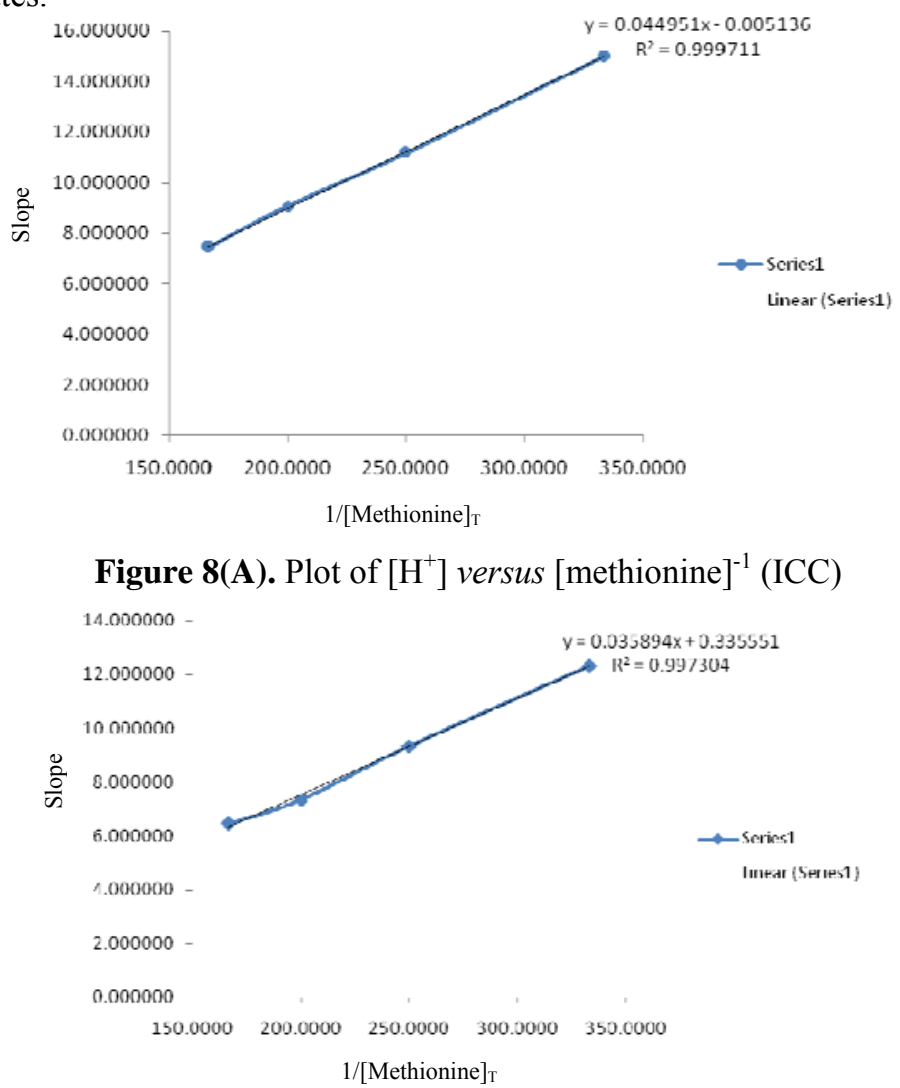

Figure 8(B). Plot of $\left[\mathrm{H}^{+}\right]$versus $[\text {methionine }]^{-1}(\mathrm{BCC})$

\section{Product analysis}

In a typical experiment for the product analysis of ICC or BCC [0.2 m mol] mixed with $0.3 \mathrm{mmol}$ of methionine at $\left[\mathrm{H}^{+}\right] 0.01 \mathrm{~mol} \mathrm{dm}{ }^{-3}$. The mixture was kept for 3 hour in a thermostat at $50{ }^{\circ} \mathrm{C}$. The total volume of the solution was initially $50 \mathrm{~mL}$. The concentrated solution was slowly evaporated to dryness in a desiccator. The IR spectra of methionine and the dried product were recorded in a SHIMADZU FTIR - 8000 spectrophotometer. In the product (Figure No $10(\mathrm{~A}) \& 10(\mathrm{~B})$ ) most of the peaks of DL - methionine were retained. A broad strong $\mathrm{NH}_{3}^{+}$stretching band appears at $3200 \mathrm{~cm}^{-1}$ in the product compared to that at $2900 \mathrm{~cm}^{-1}$ in DL - methionine (Figure 9). The shift to higher frequency is probably due to association of water with the product. A strong peak at $1600 \mathrm{~cm}^{-1}$ and a weak peak at $1400 \mathrm{~cm}^{-1}$ are obtained 
in the product ${ }^{19,20}$ due to the absorption of carboxylate group. The corresponding peaks in DL - methionine are obtained at $1500 \mathrm{~cm}^{-1}$ and $1400 \mathrm{~cm}^{-1}$ respectively. A new strong peak at $1100 \mathrm{~cm}^{-1}$ in the product is probably due to $\mathrm{S}=\mathrm{O}$ stretching vibration. The corresponding peak of the sulfoxide is obtained in 1070 to $1030 \mathrm{~cm}^{-1}$ region. From the individual assignment of different peaks it can be inferred that the product is methioninesulfoxide.
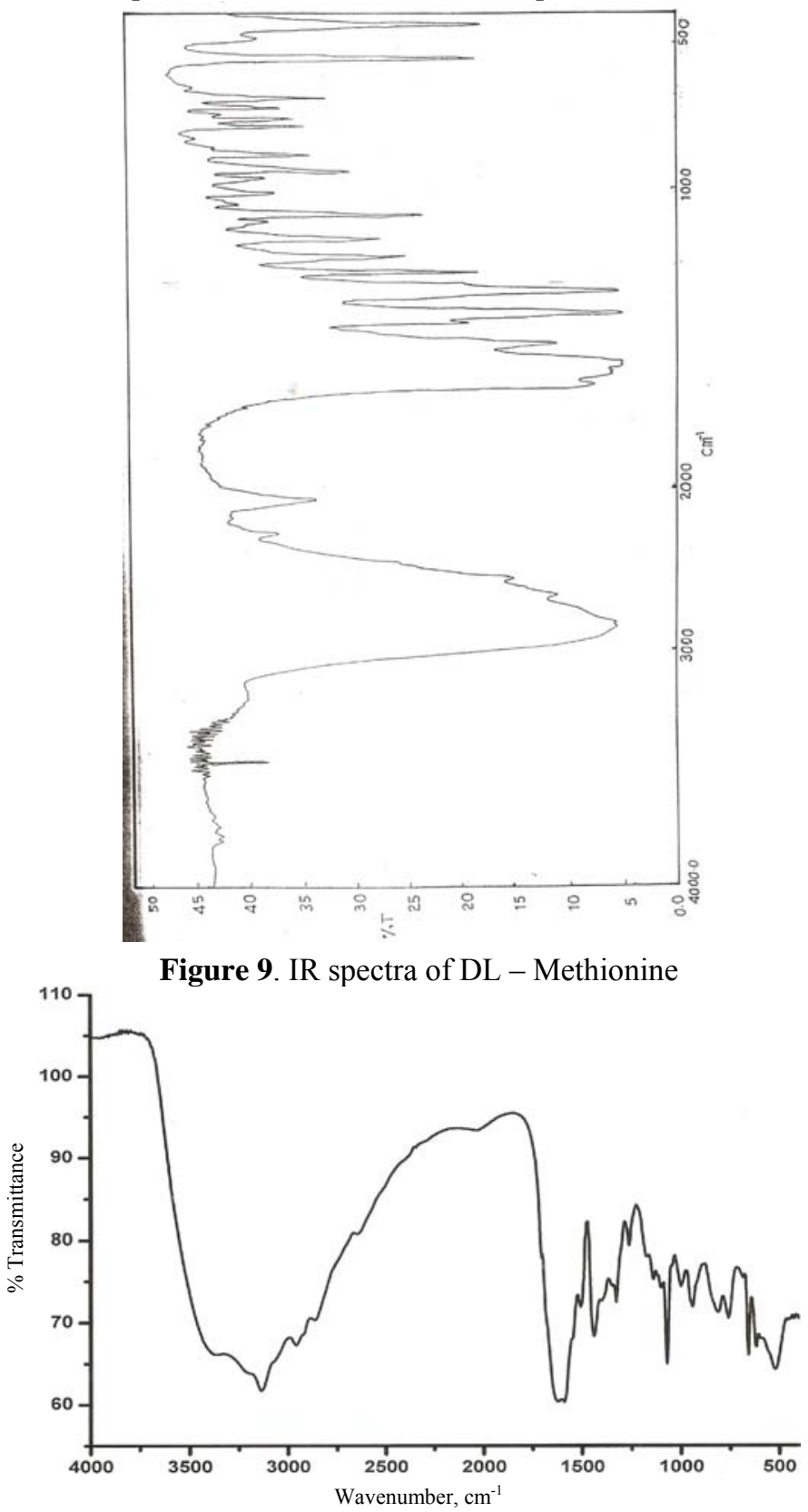

Figure 10(A). IR spectra of ICC oxidation product of methionine 


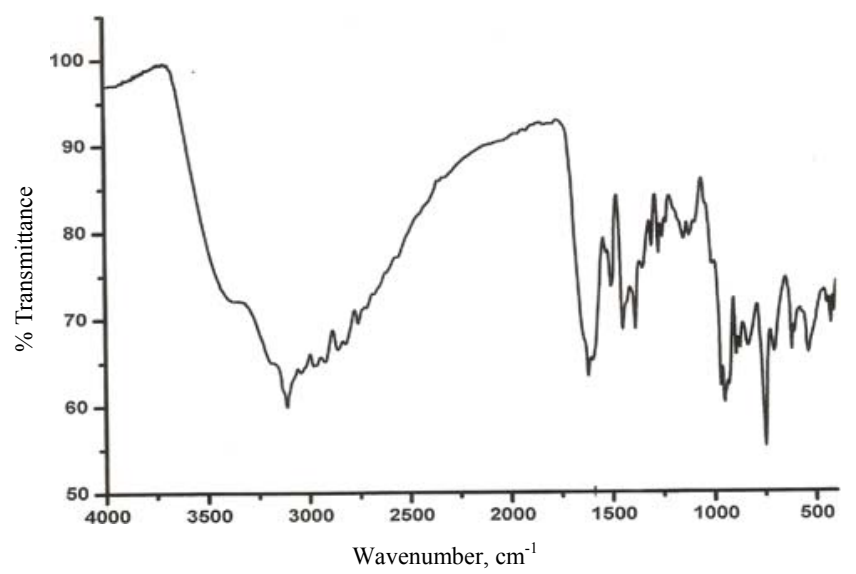

Figure 10(B). IR spectra of BCC oxidation product of methionine

\section{References}

1. Pandeswaran M, John B, Bhubaneswar D S and Elango K P, J Serb Chem Soc., 2005, 70, 145.

2. Goyal A and Kothari S, Indian J Chem., 2003, 42B, 2129.

3. Sharma V, Sharma P K and Benerji K K, Indian J Chem., 1997, 36A, 418.

4. Sharma V, Sharma P K and Benerji K K, Indian J Chem Soc., 1997, 74, 607-609.

5. Srinivasan R, Ramesh C V, Mudhulatha $\mathrm{W}$ and Balasubramanian $\mathrm{K}$, Indian J Chem., Sect B, 1996, 35, 480-484.

6. Corey E J and Suggs J W, Tetrahedron Lett., 1975, 16(31), 2647-2650.

7. Tajbakhsh M, Hosseinzadeh R and Niak M Y, J Chem Res (s)., 2002, 508-510.

8. $\quad$ Winifred M. Watkins, Carbohydrate Res., 1986, 149(1), 1-12.

9. Mamaghani M, Shirini F and Parsa F, Russian J Org Chem., 2002, 38, 1113-1115.

10. Sharma V, Mittal S and Banerji K K, J Chem Res (S), 1966, 264.

11. Mahadevappa D S, Ananda S, Made Gowdan M M and Kanchugarakoppal S Rangappa, J Chem Soc Perkin Trans., 1985, 2, 39-43.

12. Satpathy P K, Dash G C, Acharya S and Mohanty P, J Indian Chem Soc., 2006, 83, 891-894.

13. Sala F L, Palopoli C, Alba V and Signorella S, Polyhedron, 1993, 12(18), 2227-2234.

14. Meenakshisundaram S and Vinothini R, Croat Chem Acta, 2003, 76(1), 75-80.

15. Abedinzadeh Z, Can J Physiol Pharmacol., 2001, 79(2), 166-170.

16. Schonich C, Zhao F, Wilson G S and Borchardt R T, Biochem Biophys Acta (BBA), 1993, 1158(3), 307-322.

17. Agarwal S, Tiwari H P and Sharma J P, Tetrahydron, 1990, 46(6), 1963-1974.

18. Sivamurugan V, Rajkumar G A, Aurobinda B, Murugesan V, Indian J Chem., 2005, 44(1)B, 144.

19. Perrin D and Koppanol W H, Arch Biochem Biophys., 2000, 377(2), 266-272.

20. Silverstein R M, Bassler G C and Morrill T C, Spectrometric identification of organic compounds, $4^{\text {th }}$ Ed., Eds., Silverstain, Bassler and Morril, John Wiley \& Sons, New York. 